\title{
Are There Structural Alterations in the Enamel Organ of Offspring of Rats with Alloxan-Induced Diabetes Mellitus?
}

\author{
Yara Teresinha Corrêa SILVA-SOUSA ${ }^{1}$ \\ Luiz Cesar PERES ${ }^{1}$ \\ Milton César FOSS ${ }^{2}$ \\ ${ }^{1}$ Department of Patology, ${ }^{2}$ Department of Clinical Medicine, Faculty of Medicine of Ribeirão Preto, \\ University of São Paulo, Ribeirão Preto, SP, Brazil
}

\begin{abstract}
Enamel hypoplasia is the most common developmental defect of human teeth that may be seen in deciduous teeth of babies born to diabetic women. In the present experimental study, we analyzed the enamel organ of the mandibular incisors of the offspring of rats with alloxan-induced diabetes. By light microscopy, no alterations could be found in the enamel organ of rats born to diabetic mothers compared to normal ones, except in one case. In contrast, significant differences were detected with computer-aided morphometry. In the rats born to treated and untreated diabetic mothers, there was thinning of the enamel matrix and of the ameloblasts and the nuclear area of the latter was smaller. In the rats born to treated diabetic mothers, the nuclei of the ameloblasts were more elliptical and there was enlargement of the interstitial area of the stellate reticulum. These results indicate that there are structural defects in the enamel organ of rats born to mothers with alloxan-induced diabetes which could induce the enamel hypoplasia observed by scanning electron microscopy and which may reflect the metabolic alterations seen in this condition. Future studies are needed to determine whether these effects are transitory or permanent.
\end{abstract}

Key Words: experimental diabetes, enamel hypoplasia, enamel disturbances, ameloblasts, alloxan.

\section{INTRODUCTION}

Enamel hypoplasia is the most common of the changes in human tooth development, with relevant clinical implications due to esthetic reasons, symptoms involved, susceptibility to caries, and also to the difficulty of treatment in many cases. This condition occurs as a direct result of disorders of metabolism of the ameloblast layers of the enamel organ. The specific etiological agents or the events responsible for the deleterious changes in the metabolism of these cells can be divided into three categories: localized mechanical trauma, systemic diseases and hereditary factors (1).

Research has shown the relationship of enamel hypoplasia with several alterations such as low birth weight (2), neonatal tetany (3), fetal erythroblastosis (4), hypoparathyroidism/pseudo-hypoparathyroidism and vitamin D-dependent rickets (5), hereditary bullous epidermolysis (6), malnutrition (7), toxic fluoride in- gestion (8), natal or neonatal teeth (9), root canal infection and traumatic injury to deciduous teeth (8), and orotracheal intubation during the neonatal period (2).

In addition to the alterations that occur during the perinatal period and infancy, systemic changes during pregnancy can also interfere with tooth formation, resulting in enamel hypoplasia in deciduous teeth. The occurrence of hypoplastic deciduous teeth in children of diabetic mothers has been frequently reported $(1,10)$. Experimentally induced disturbances of dental enamel formation are being studied to elucidate the mechanisms involved in the occurrence of enamel hypoplasia. Among the models proposed to study the changes in dental enamel, we may point out the administration of tetracycline (11), a calcium-deficient diet (12), endocrine changes provoked by thyro-parathyroidectomy (13), intoxication with heavy metals such as lead, cadmium and zinc (14) and diabetogenic drugs such as alloxan (15) and streptozotocin (16). 
Despite clinical evidence of a high incidence of enamel hypoplasia in diabetic children and in children of diabetic mothers, limited attention has been paid to the study of the mechanism of dental tissue formation in the presence of diabetes mellitus. A previous study of the dental enamel surface of pups from rats with alloxan diabetes induced before pregnancy showed different degrees of dental enamel impairment by scanning electron microscopy. The changes observed in the enamel depended on maternal blood glucose levels and were correlated with the dental enamel hypoplasia observed in humans (15).

Thus, the objective of the present study was to analyze by light microscopy and morphometry the enamel organ of the mandibular incisors of offspring of rats with alloxan diabetes induced before pregnancy.

\section{MATERIAL AND METHODS}

The study was conducted on 18 albino Wistar rats weighing 180-200 $\mathrm{g}$ receiving an appropriate commercial ration and water ad libitum.

Diabetes was induced in 12 rats with a single dose of $40 \mathrm{mg} / \mathrm{kg}$ alloxan and 6 animals were used as controls. Daily supplementation with 1.0 IU NPH insulin was provided by subcutaneous injection until the end of mating to prevent infertility.

After mating, the diabetic female rats were divided into two groups of 6 animals each. One group continued to receive insulin during pregnancy (group II) and the other did not (group III).

Blood glucose levels were determined by the glucose-oxidase method 1 day before the induction of diabetes, 1 day after the induction of diabetes, 1 day before mating, and 15 days after mating.

Two pups from each litter were selected at ran-

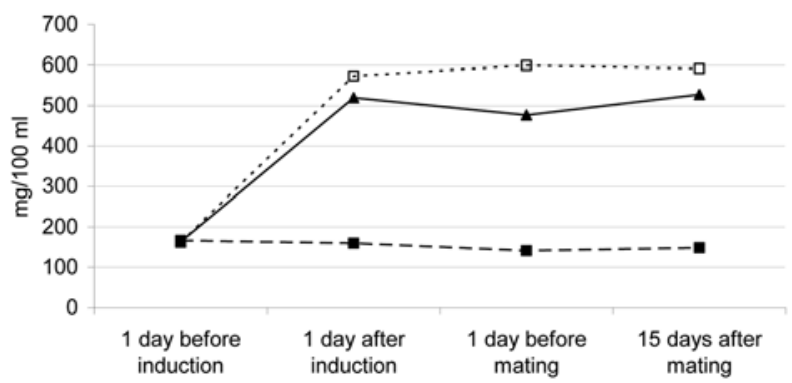

Figure 1. Mean blood glucose levels of female rats of groups I (closed squares), II (closed triangles) and III (open squares) $(\mathrm{N}=$ $6)$. dom at 7 days of age and sacrificed by decapitation. The hemimandibles were carefully dissected, fixed in paraformaldehyde, decalcified in Morquio solution (equal parts of $20 \%$ sodium citrate and $50 \%$ formic acid) for approximately $24 \mathrm{~h}$, and individually processed for paraffin embedding. Consecutive $4-\mu \mathrm{m}$ thick longitudinal sections were stained with hematoxylineosin.

The morphological study was conducted in two stages: a) light microscopy analysis of the enamel organ in the final part of the stage of enamel secretion using a Leitz Wetzlar microscope (Wetzlar, Germany), and b) morphometric analysis of the enamel matrix formed and of the enamel organ in the final phase of the secretion stage using the Scion Image for Windows software (Scion Corporation, Maryland, USA). The following parameters were evaluated: thickness of the enamel matrix, ameloblast height, area of the ameloblast nucleus, ratio of the largest and smallest diameters of the ameloblast nucleus, thickening of the intermediate layer, thickness of the stellate reticulum, and area corresponding to the interstitium of the stellate reticulum.

\section{RESULTS}

The mean blood glucose levels, expressed as $\mathrm{mg} / 100 \mathrm{ml}$, for control rats (group I), diabetic rats treated with insulin (group II) and diabetic rats that did not receive insulin treatment after mating (group III) are presented in Figure 1. When the data were analyzed by the Kruskal-Wallis test at the $1 \%$ level of significance, a significant difference was observed between the control and treated groups. With respect to groups II and III, significant differences in blood glucose levels were observed 1 day before mating.

\section{Light Microscopy}

A panoramic view of the dental germ showed that on the $7^{\text {th }}$ day of life the odontogenesis of the mandibular incisors was in the crown phase, with the presence of cells of the enamel organ in various stages of differentiation. The different stages of amelogenesis were defined and recognized on the basis of the morphological aspect of the cells.

No significant changes were observed by light microscopy in the final stage of enamel secretion in 
groups II and III (Figure 2A), except for a single case. A group II animal presented marked changes in the ameloblast layer, with the presence of irregular cells with rounded nuclei irregularly arranged along the entire
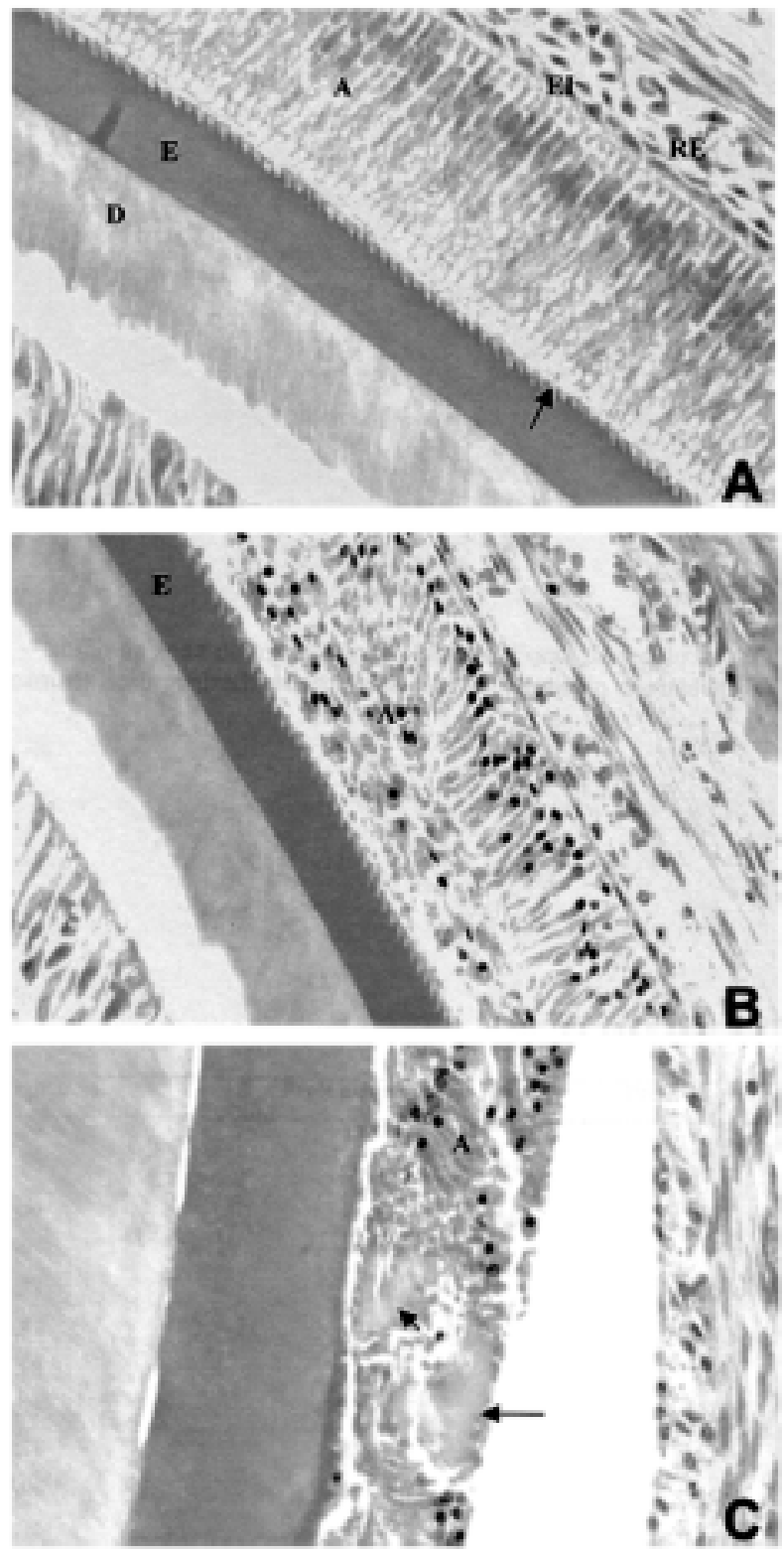

Figure 2. A: Enamel secretion zone of a control animal. Enamel matrix (E), dentine (D), secretory ameloblasts (A), intermediate stratum (EI), stellate reticulum (RE). Note the characteristic projections of Tomes' processes (arrow) (Original magnification 400X). B: Ameloblast layer alteration in a case of group II. The ameloblasts are irregularly shaped and arranged (A) but the enamel layer is normal (E) (Original magnification 400X). C: Same animal with lesion in the enamel maturation zone. Note the disorganized ameloblast layer (A) with foci of mineralization (arrow) (Original magnification 400X). enamel organ (Figure 2B). Projections corresponding to the Tomes processes were observed in the secretion zone, as well as an enamel layer which did not differ histologically from those observed in the control group. Focal points of mineralized tissue among the cells of the ameloblastic layer were observed in the maturation zone (Figure 2C).

\section{Morphometric Analysis}

The results of the morphometric analysis were submitted to previous statistical analysis in order to define the characteristics of sample distribution and thus permit the choice of an appropriate statistical test. Data concerning enamel matrix thickness, ameloblast height, ratio between the largest and smallest diameter of the ameloblast nucleus, thickness of the intermediate layer and area corresponding to the interstitium of the stellate reticulum presented normal distribution and were analyzed by parametric tests, i.e., analysis of variance and Tukey test, with the level of significance set at $5 \%$ in both cases. The

Table 1. Mean values of the parameters submitted to analysis by parametric tests ANOVA and Tukey $(\mathrm{N}=12)$.

\begin{tabular}{lrrr}
\hline & Control & $\begin{array}{c}\text { Treated } \\
\text { diabetic rats }\end{array}$ & $\begin{array}{r}\text { Untreated } \\
\text { diabetic rats }\end{array}$ \\
\hline Enamel thickness $(\mu \mathrm{m})$ & $14.47979^{\mathrm{a}}$ & $11.46775^{\mathrm{b}}$ & $9.80233^{\mathrm{b}}$ \\
Ameloblast height $\left(\mu \mathrm{m}^{2}\right)$ & $47.15083^{\mathrm{a}}$ & $42.58484^{\mathrm{b}}$ & $36.18091^{\mathrm{c}}$ \\
$\mathrm{D} / \mathrm{d}($ ameloblast nucleus) & $2.55917^{\mathrm{a}}$ & $2.90167^{\mathrm{b}}$ & $2.61500^{\mathrm{a}}$ \\
$\begin{array}{l}\text { Intermediate layer } \\
\text { thickness }(\mu \mathrm{m})\end{array}$ & $2.29923^{\mathrm{a}}$ & $2.18643^{\mathrm{a}}$ & $2.16456^{\mathrm{a}}$ \\
$\begin{array}{l}\text { Area of the interstitium } \\
\text { of the stellate reticulum }\end{array}$ & $42.28^{\mathrm{a}}$ & $52.59^{\mathrm{b}}$ & $44.13^{\mathrm{a}}$ \\
\hline
\end{tabular}

Different letters indicate statistically significant differences.

Table 2. Mean values of the parameters submitted to analysis by the Kruskal-Wallis test $(\mathrm{N}=12)$.

\begin{tabular}{cccc}
\hline & Control & $\begin{array}{c}\text { Treated } \\
\text { diabetic rats }\end{array}$ & $\begin{array}{c}\text { Untreated } \\
\text { diabetic rats }\end{array}$ \\
\hline $\begin{array}{c}\text { Ameloblast nucleus } \\
\text { area }\left(\mu \mathrm{m}^{2}\right)\end{array}$ & $31.61807^{\mathrm{a}}$ & $28.89008^{\mathrm{b}}$ & $26.43972^{\mathrm{b}}$ \\
$\begin{array}{c}\text { Stellate reticulum } \\
\text { thickness }(\mu \mathrm{m})\end{array}$ & $15.57750^{\mathrm{a}}$ & $14.48445^{\mathrm{a}}$ & $14.31292^{\mathrm{a}}$ \\
\hline
\end{tabular}

Different letters indicate statistically significant differences. 
results are reported in Table 1.

The data concerning ameloblast nucleus area and stellate reticulum thickness presented non-normal distribution and were submitted to the nonparametric Kruskal-Wallis test, with the level of significance set at $1 \%$, and to the test for rank means. The results are reported in Table 2.

\section{DISCUSSION}

The frequent association between diabetes and pregnancy has led to the characterization of a clinical class denoted gestational diabetes which includes pregnant patients whose diabetes starts or is first diagnosed during the gestational period (17).

Hyperglycemia in pregnant women is known to have deleterious effects on fetal development, increasing the risk of congenital malformations (18), which continue to be the major cause of morbidity in this group. Hyperglycemia during the gestational period can also affect the dental enamel development during this period, causing enamel hypoplasia in the deciduous teeth of children born to diabetic mothers $(1,10)$.

Experimental diabetes can be induced surgically by pancreatectomy or chemically by the administration of alloxan or streptozotocin. In the present study, we opted for alloxan-induced diabetes because it is a method of easy execution, which permits the occurrence of diabetic status in a high percentage of animals with characteristics similar to those of diabetes mellitus of humans. The model of diabetes induced with alloxan before pregnancy was used in a previous study and yielded satisfactory results both in terms of hyperglycemia and in terms of the observation of defects on the surface of dental enamel (15). The blood glucose levels obtained in the present study with alloxan-induced diabetes indicate that the method used was effective, producing a hyperglycemic state observable as early as $24 \mathrm{~h}$ after induction and lasting throughout the experiment. The option of inducing diabetes with alloxan before pregnancy was used to prevent the toxic acute effects of the drug on fetal development.

Literature reports the occurrence of ultrastructural alterations in the secretory ameloblasts of rat incisors after the induction of experimental diabetes $(15,16)$. Silva-Sousa $(15)$ analyzed qualitatively by scanning electron microscopy the morphological aspect of the surface of dental enamel of offspring of rats with alloxan diabetes induced before pregnancy. Enamel alterations of varying degrees depending on the maternal blood glucose levels were observed and were found to be similar to the dental enamel hypoplasia observed in humans.

The animal's age selected (7 days) for the analysis of the enamel organ was based on the fact that the dental tissues observed at this age were formed during intrauterine life, in this case under the influence of the maternal hyperglycemic status.

Since the incisors of rodents present continuous development and a single section can show the various stages of the life cycle of ameloblasts as well as the phases of secretion, calcification and maturation of the enamel matrix (19), it is of fundamental importance that the analyses be conducted on the same region of the enamel organ. Thus, the morphological and morphometric analyses were limited to the final stage of secretion of the enamel organ since in this phase the enamel matrix has developed to its full thickness with a sufficient amount of preserved organic matter, which serves for histological determination of the structural organization of this tissue.

Morphological analysis by light microscopy of the dental germs showed that, on the $7^{\text {th }}$ day of the animal's life, the odontogenesis of the mandibular incisor was in the crown phase, permitting observation of the cells of the inner epithelium of the enamel organ in different stages of differentiation.

In the present study, light microscopy did not reveal significant changes in the enamel organ of pups from diabetic dams, except for a single animal in group II which presented marked alterations in the ameloblast layer. Although these changes occurred in a single case, it is important to point out that the animal in question was from the dam that presented the highest blood glucose levels during the experiment, i.e., $911 \mathrm{mg} / 100$ $\mathrm{ml}$ on the $15^{\text {th }}$ day after mating. Similar changes were observed when the effect of tetracycline on the secretory ameloblasts of rat teeth was investigated (11).

The mean thickness of the enamel matrix observed in offspring of diabetic dams (groups II and III) was lower than that observed in the control group, clearly showing that the secretion of the enamel matrix was decreased in the experimental groups, forming a thinner enamel layer.

Significant differences in ameloblast height were observed between the three groups, with lower mean 
values being observed in groups II and III. The nuclei of the ameloblasts were analyzed in terms of two parameters. The mean values corresponding to the area of the nucleus showed that the pups from diabetic dams presented smaller nuclei than control animals. Analysis of the ratio between the largest and smallest diameter of the nucleus showed that pups from diabetic dams treated with insulin (group II) had a more elongated nucleus than the other animals studied.

No significant differences were observed in the thickness of the intermediate layer or of the stellate reticulum between the three groups studied. With respect to the area corresponding to the interstitium of the stellate reticulum, we observed that pups from diabetic dams treated with insulin (group II) presented a higher percentage $(52.59 \%)$ than pups from groups I $(42.28 \%)$ and III $(44.13 \%)$. Considering that increased permeability of the basement membrane of different tissues occurs in diabetic patients, we may assume that the increase in the area corresponding to the interstitium of the stellate reticulum is due to an increase in fluid promoted by the greater permeability of blood vessels present in the region. At the beginning of the secretory phase of amelogenesis, the volume of the stellate reticulum is reduced due to the loss of its intercellular material in order to permit the outer epithelium to reach the intermediate layer, facilitating the arrival of nutrients to the intermediate layer, where they will be pre-metabolized, later reaching the ameloblasts (20).

On the basis of these observations, we may assume that the increase in the area relative to the interstitium of the stellate reticulum observed in animals whose mothers presented marked hyperglycemia might have prevented nutrients from reaching the secretory ameloblasts, resulting in changes in the secretion of the organic matrix of enamel.

The alterations observed in diabetes, both human and experimental, are not only due to blood glucose levels but also to intracellular functional changes brought about by metabolic adaptations secondary to the lack of intracellular glucose. Under these conditions, metabolites arise that may interfere with other biochemical processes or lead to morphological cellular changes at distinct sites. It was not an objective of the present study to determine the pathogenic mechanisms involved in the model, but only to determine and characterize the morphological changes existing in the enamel organ of the offspring of diabetic rats.
On the basis of the results obtained, we may conclude that analysis by light microscopy did not show significant changes in the enamel organs of pups born to diabetic mothers, except for a single case. With respect to morphometric analysis, we observed that 1) the enamel matrix was thinner in the experimental groups, 2) the secretory ameloblasts of pups from diabetic dams were shorter than those of the control group, 3 ) the ameloblast nuclei were smaller in pups from diabetic dams and more elongated in pups from insulintreated diabetic dams than in the other animals studied, and 4) the area of the interstitium of the star-shaped reticulum was larger in pups from insulin-treated dams than in the other animals studied.

\section{ACKNOWLEDGMENTS}

The authors thank Adalberto V. Verceze, Maurício R. Arantes, Roni C. Fabbris and Sebastião L. Brandão Filho, from the Departamento de Clínica Médica (FMRP-USP), for their help with the animals and Deise L.C. Simões, from the Departamento de Patologia (FMRP-USP), for the histology work.

\section{RESUMO}

A hipoplasia de esmalte é a mais comum dentre as alterações de desenvolvimento do dente humano, e ocorre com freqüência em dentes decíduos de filhos de mães diabéticas. O presente estudo experimental analisou, por meio de microscopia óptica e morfometria, o órgão do esmalte de incisivos inferiores de filhotes de ratas com diabetes aloxânico, induzido previamente à gestação. Os resultados mostraram que não foram observadas pela microscopia óptica alterações significantes nos germes dentais dos animais descendentes de ratas diabéticas, com exceção de um caso. A análise morfométrica dos órgãos do esmalte de ratos nascidos de mães diabéticas tratadas e não tratadas evidenciou as seguintes diferenças estatisticamente significantes: menor espessura da matriz de esmalte, menor altura dos ameloblastos e área de seus núcleos. Nos animais nascidos de ratas diabéticas tratadas, observou-se núcleos dos ameloblastos mais elípticos e aumento da área correspondente ao interstício do retículo estrelado. Estes resultados indicam que há alterações estruturais no órgão do esmalte de descendentes de ratas com diabetes aloxânico as quais poderiam induzir a hipoplasia do esmalte dental visto por microscopia eletrônica de varredura, possivelmente refletindo as alterações metabólicas observadas nesta condição. Estudos futuros devem ser realizados a fim de determinar se estas alterações são transitórias ou permanentes.

\section{REFERENCES}

1. Via Jr WF, Churchill JA. Relationship of the hypoplasia to abnor- 
mal events of gestation and birth. J Am Dent Assoc 1959;59:702707.

2. Fearne JM, Bryan EM, Elliman AM, Brook AH, Williams DM. Enamel defects in the primary dentition of children born weighing less than $2000 \mathrm{~g}$. Br Dent J 1990;168:433-437.

3. Purvis RJ, Barrie WJ, MacKay GS, Wilkinson EM, Cockburn F, Belton NR. Enamel hypoplasia of the teeth associated with neonatal tetany: a manifestation of maternal vitamin-D deficiency. Lancet 1973;13:811-814.

4. Cullen CL. Erythroblastosis fetalis produced by Kell immunization: dental findings. Pediatr Dent 1990;12:393-396.

5. Nikiforuk G, Fraser D. The etiology of enamel hypoplasia: A unifying concept. J Pediatrics 1981;98:888-893.

6. Wright JT, Fine JD, Johnson L. Hereditary epidermolysis bullosa: oral manifestations and dental management. Pediatr Dent $1993 ; 15: 242-248$.

7. Rugg-Gunn AJ, Al-Mohammadi SM, Butler TJ. Malnutrition and developmental defects of enamel in 2- to 6-year-old Saudi boys. Caries Res 1998;32:181-192

8. Suckling GW, Herbison GP, Brown RH. Etiological factors influencing the prevalence of developmental defects of enamel in nine-year-old New Zealand children participating in a health and development study. J Dent Res 1987;66:1466-1469.

9. Motoyama LCJ, Lopes LD, Watanabe I-S. Natal teeth in cleft lip and palate patients: a scanning electron microscopy study. Braz Dent J 1996;7:115-119.

10. Norén JG. Microscopic study of enamel defects in deciduous teeth of infants of diabetic mother. Acta Odontol Scand 1984;42:153-156.
11. Kallenbach E. Microscopy of tetracycline-induced lesions in the rat incisor enamel organ. Arch Oral Biol 1979;24:869-876.

12. Lozupone E, Favia A. Effects of a low calcium maternal and weaning diet on the thickness and microhardness of rat incisor enamel and dentine. Arch Oral Biol 1989;34:491-498.

13. Chardin H, Acevedo AC, Risnes S. Scanning electron microscopy and energy-dispersive X-ray analysis of defects in mature rat incisor enamel after thyroparathyroidectomy. Arch Oral Biol 1998;43:317-327.

14. Gerlach RF, Souza AP, Cury JA, Line SR. Effect of lead, cadmium and zinc on the activity of enamel matrix proteinases in vitro. Eur J Oral Sci 2000;108:327-334.

15. Silva-Sousa YTC, Peres LC, Foss MC. Enamel hypoplasia in a litter of rats with alloxan-induced diabetes mellitus. Braz Dent $\mathrm{J}$ 2003; $14: 87-93$

16. Ryan EA, Tobin BW, Tang J, Finegood DT. A new model for study of mild diabetes during pregnancy. Syngeneic islet-transplanted STZ-induced diabetes rats. Diabetes 1993;42:316-323.

17. Alberti KG, Zimmet PZ. Definition, diagnosis and classification of diabetes mellitus and its complications. Part 1: diagnosis and classification of diabetes mellitus provisional report of a WHO consultation. Diabet Med 1998;15:539-543.

18. Pedersen LM, Tygstrup I, Pedersen J. Congenital malformations in newborn infants of diabetic women. Correlation with maternal diabetic vascular complications. Lancet 1964;1:1124-1126.

19. Leblond CP, Warshawsky H. Dynamics of enamel formation in the rat incisor tooth. J Dent Res 1979;58:950-975.

20. Maia Campos G. Ameloblastoma, a behavioral and histologic paradox (A philosophical approach). Braz Dent J 1990;1:5-15.

Accepted February 24, 2003 